\title{
A Translation of the Malia Altar Stone
}

\author{
Peter Z. Revesz $z^{1, a}$ \\ ${ }^{1}$ Department of Computer Science, University of Nebraska-Lincoln, Lincoln, NE, 68588, USA
}

\begin{abstract}
This paper presents a translation of the Malia Altar Stone inscription (CHIC 328), which is one of the longest known Cretan Hieroglyph inscriptions. The translation uses a synoptic transliteration to several scripts that are related to the Malia Altar Stone script. The synoptic transliteration strengthens the derived phonetic values and allows avoiding certain errors that would result from reliance on just a single transliteration. The synoptic transliteration is similar to a multiple alignment of related genomes in bioinformatics in order to derive the genetic sequence of a putative common ancestor of all the aligned genomes.
\end{abstract}

\section{Introduction}

Cretan Hieroglyph is a writing system that existed in eastern Crete c. 2100 - 1700 BC $[13,14,25]$. The full decipherment of Cretan Hieroglyphs requires a consistent translation of all known Cretan Hieroglyph texts not just the translation of some examples. In particular, many authors have suggested translations for the Phaistos Disk, the most famous and longest Cretan Hieroglyph inscription, but in general they were unable to show that their translation method is also applicable to the other known Cretan Hieroglyph texts. As one of a few exceptions, the author proposed both a translation of the Phaistos Disk [18] and a consistent translation of some short Cretan Hieroglyph inscriptions [19]. However, the translation of medium length Cretan Hieroglyph inscriptions remained an open problem, which is addressed in this paper.

The Malia Altar Stone, which was found by a farmer in 1937, is a blue limestone slab with a cuplike cavity on its top and a medium length Cretan Hieroglyph inscription consisting of sixteen letters on its side as described by Chapouthier [7]. The Malia Altar Stone is thought to be an offering table with some liquid placed in its cuplike cavity. The exact date of the Malia Altar Stone cannot be determined, but it is considered to be a Minoan artifact. Olivier et al. [14] list the Malia Altar Stone as item number 328 in the Corpus Hieroglyphicarum Inscriptionum Cretae (CHIC).

Many authors noted some visual relationships between the Cretan Hieroglyph script symbols and the Linear A, the Linear B and the Anatolian Hieroglyph script symbols. The common assumption was that the known sound values of Linear B and Anatolian Hieroglyph script symbols could be projected back to similar-looking Cretan Hieroglyph and Linear A script symbols. These attempts so far were not successful in deciphering the later two scripts.

Using ideas and methods from bioinformatics, Revesz [20] analyzed the evolutionary relationships within the Cretan script family, which includes the following scripts: Cretan Hieroglyph, Linear A, Linear B [6], Cypriot, Greek, Phoenician, South Arabic, Old Hungarian $[9,10]$, which is also called rovásírás in Hungarian and also written sometimes as Rovas in English language publications, and Tifinagh.

Revesz [20] found that Cypriot and Old Hungarian were closest to Cretan Hieroglyph. This study implied that Cypriot and Old Hungarian phonetic values could be more fruitful than Linear B phonetic values to project back to Cretan Hieroglyphs. That approach was used to translate the Phaistos Disk [18] and some short Cretan Hieroglyph inscriptions [19]. (In addition, Linear B was evolutionarily closest to Linear A, giving some justification for projecting Linear B phonetic values to Linear A.)

Using a specific projection of Linear B phonetic values to Cretan Hieroglyphs, Boutsikos translated both the Phaistos Disk and the Malia Altar Stone as an ancient Greek writing [3]. In particular, for the Malia Altar Stone, he obtained the following translation: "Cares for trust and quantity goddess Mene path you correct."

Using a combination of projections from Anatolian Hieroglyph script phonetic values and Linear B script phonetic values, Best and Woudhuizen [23] translated the Malia altar stone as a Luwian document with the following meaning: "This inscribed altar stone for Baluzitis, delivery: Skheria."

Lia Rietveld in [1], pages 94-95, used a similar projection from Anatolian Hieroglyphs to translate the Phaistos Disk as a Luwian letter written to King Nestor of Pylos. Further extending this approach with some

\footnotetext{
${ }^{\mathrm{a}}$ Corresponding author: revesz@cse.unl.edu
} 
phonetic projections from Egyptian Hieroglyph, Woudhuizen [23] translated several other Cretan Hieroglyph texts, including the Arkalochori Axe inscription as a Luwian text.

The approaches of Boutsikos and of Woudhuizen and his co-workers are noted here as some of the more serious translation attempts because they consider several Cretan Hieroglyph texts. A discussion of other translation attempts and their limitations can be found in Duhoux [8].

This paper is organized as follows. Section 2 describes the translation method. Section 3 presents a translation of the Malia Altar Stone inscription. Finally, Section 4 gives some conclusions and directions for future work.

\section{The translation method}

Our translation method is necessarily based on some assumptions about the Cretan Hieroglyph writing system. In particular, we need to classify the Cretan Hieroglyph writing system among the known categories.

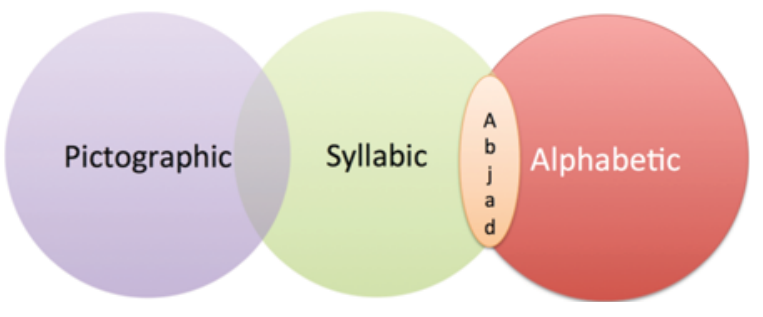

Fig. 1. A classification of writing systems .

In general, writing systems can be divided into pictographic, syllabic and alphabetic system as shown in Fig. 1. In pictographic writing systems, each symbol denotes a single word. Pictographic writing systems are limited in vocabulary and cannot express grammatical features

In syllabic writing systems, each symbol denotes a single syllable. For example, Linear $\mathrm{B}$ is a syllabic writing system where in general each syllable begins with a single consonant $\mathrm{C}$, which is followed by a single vowel V to form simple CV-type syllable. Such a syllabic writing is conveniently represented in a syllabic grid, where each row stands for a consonant and each column stands for a vowel.

In alphabetic writing systems, each symbol represents a single sound. In abjad writing systems each symbol represents a consonant, but when the text is read the vowels that implicitly lie between the consonants are pronounced together with those consonants. Arabic and Hebrew are examples of abjad writing systems, although they also use occasionally some symbols that represent vowels to avoid potential ambiguities. Abjad writing systems can be thought of as the intersection of syllabic and alphabetic writing systems because they share some features with both of those writing systems.

Old Hungarian $[9,10]$ can be characterized as a partial-abjad script because most of the time only the consonants are explicitly written down while the vowels are only implicit. However, Old Hungarian has more number of vowels than Arabic or Hebrew have. Hence in Old Hungarian the chance of ambiguity is always higher if in a word a vowel is omitted. On the other hand, Old Hungarian inscriptions take advantage of vowel harmony within words. In languages with vowel harmony, each word contains only all high or deep vowels and in fact frequently all the vowels are the same. Hence it is enough to indicate only the first vowel and omit the rest of the vowels. Table 1 illustrates the various writing systems.

Table 1. Different types of writing systems.

\begin{tabular}{|l|l|l|}
\hline \multicolumn{1}{|c|}{ Type } & $\begin{array}{c}\text { Possible Way of } \\
\text { Writing "Knossos" }\end{array}$ & $\begin{array}{c}\text { Writing System } \\
\text { Examples }\end{array}$ \\
\hline Syllabic & Ko-no-so & Linear B \\
\hline Partial Abjad & K-n-o-s-s-s & Old Hungarian \\
\hline Abjad & K-n-s-s-s & Arabic, Hebrew \\
\hline Alphabetic & K-n-o-s-s-o-s & English, Latin \\
\hline
\end{tabular}

What is the type of the Minoan writing system? Most experts say that writing developed from some initial pictogram writing, to syllabic writing, then partial-abjad writing, then abjad writing and finally an alphabetic writing. Most experts also agree that the Minoan writing seems more complex than pictograms and is not an alphabetic writing. It is therefore usually assumed that the Minoan writing is syllabic. Linear B is syllabic and it would seem impossible to that Linear A is a partial-abjad or an abjad, when Linear B is a later development of Linear A and Cretan Hieroglyphs.

However, we would like to propose that the Minoan writing system is a partial-abjad. As writing advances from pictograms, the next stage could be either syllabicin case there is no vowel harmony and a larger set of vowels in the underlying language - or a partial-abjadin case there is vowel harmony or only a few vowels. The rational of this hypothesis is that with either vowel harmony or with few vowels, the implicit vowels become easily guessable hence a partial-abjad or abjad writing can be efficiently applied. We believe that the Minoan language had either vowel harmony or few vowels and could naturally develop into a partial-abjad. In contrast, Mycenaean Greek had a larger number of vowels and lacked vowel harmony. Hence Mycenaean Greek naturally developed into a syllabic writing.

Our translation method uses the following steps. First, we use what we call synoptic transliteration to identify the phonetic values of all the symbols. Synoptic transliteration means that we compare each symbol with several different cognate symbols from other alphabets and syllabaries. Although individual symbols may change their phonetic values, when the phonetic values agree, then it is highly probable that the phonetic value of the 


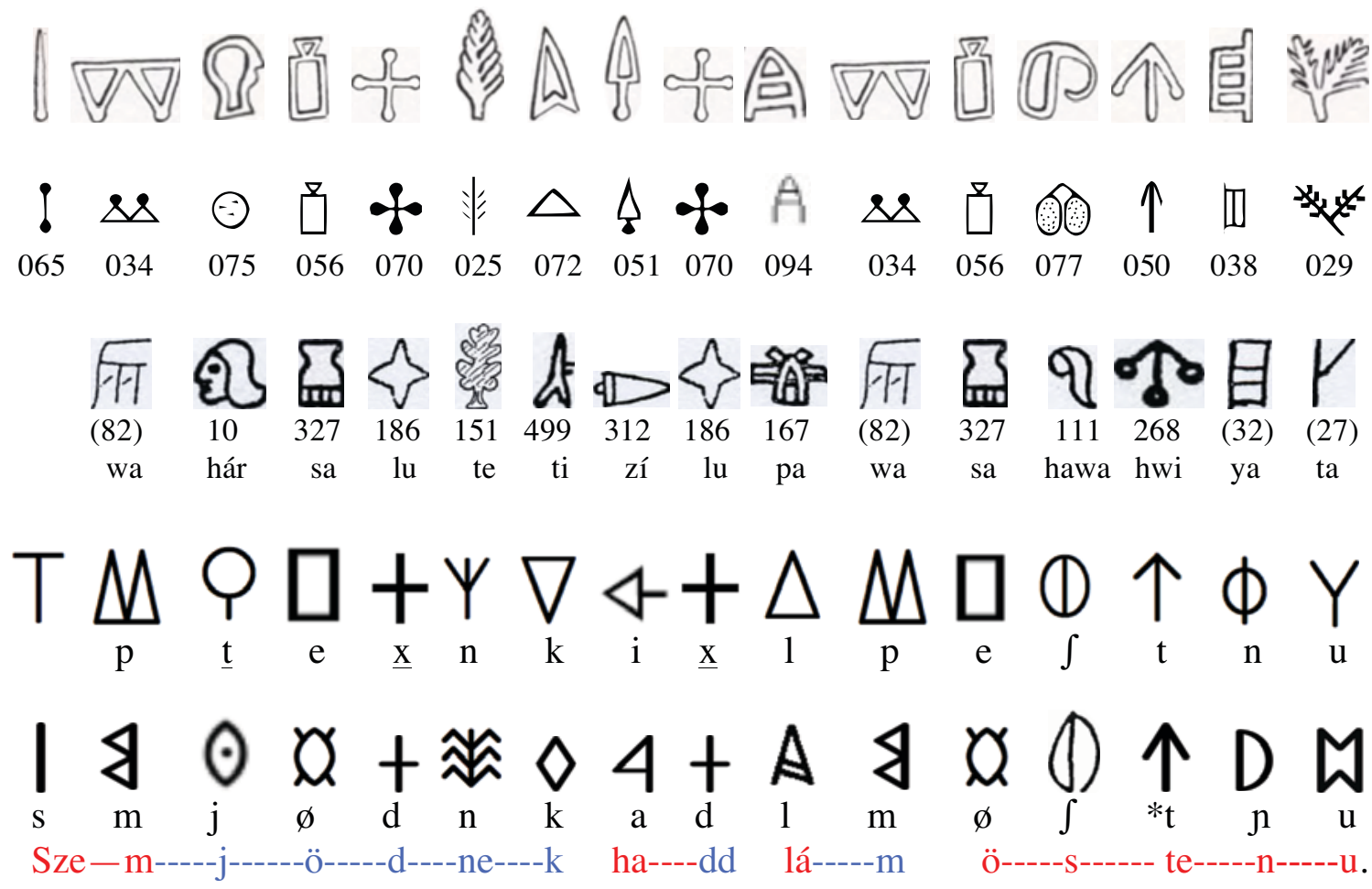

Fig. 2. The Malia Altar Stone inscription (first row), its transliteration into Cretan Hieroglyphs (second row), Anatolian/Luwian Hieroglyphs (third row), the Carian alphabet (fourth row) and the Old Hungarian alphabet (fifth row). The syllabic values are indicated below the Anatolian (Luwian) symbols, and the IPA sound values are indicated below each Carian and the Old Hungarian letter. In the bottom the translation is shown with root words in red and suffixes in blue.

Malia Altar Stone symbol was the same as the phonetic value of its cognate symbols. In case of disagreements, we consider which phonetic value may be the original.

Second, we fill in the missing vowels as is required by a partial abjad writing system, the main guide here is that with the additions, we obtain meaningful words and sentences in the Proto-Finno-Ugric, Proto-Ugric and Proto-Hungarian languages, which were also used to aid in the translation of the Phaistos Disk [17, 18], under the assumption that the Minoan language could be classified to also belong to the Finno-Ugric group of languages. The fill-in process was partially automated by the use of a database of proto-words from Zaicz [26] to aid searching for proto-words that match the phonetic values in the text.

\section{The translation result}

Chapouthier [7] assumed a right-to-left reading direction of the Malia altar stone inscription. The top of Fig. 2 shows a reordering of the signs of his drawing to allow a left-to-right reading direction. Several other Cretan Hieroglyph inscriptions have the same sequence of three or two signs. For example, the beginning sequence

\section{吕 o 粘}

of CHIC $118 \mathrm{a}$ matches the $4^{\text {th }}, 5^{\text {th }}, 6^{\text {th }}$ and perhaps also the $7^{\text {th }}$ sign of the Malia altar stone. Similarly, the sequence

\section{\&}

occurs within CHIC 49 and 61 followed by a number, which suggests that this pair can denote some commodity. Since the first sign may depict breasts and the second sign some container, the commodity may be bottles of milk. CHIC 178, 238, 244, 248, 260, 281, 295, 296 and 310 also contain the above pair of signs, in each case following the $x$ sign.

The third sign of the Malia altar stone inscription denotes some head. A sheep head followed by a $\bar{\square}$ sign occurs in CHIC 013, 015, 024 and 297, while a cow head followed by a 5 sign occurs in CHIC 002. In some of these cases, the heads may be logograms indicating sheep milk or cow milk, respectively. However, in the Malia Altar Stone inscription the head sign may denote a human head. A human torso $\&$ follows a $\&$ sign in CHIC 058.

Finally, like the Malia Altar Stone, CHIC 072 may end with $\square$ or it may begin with $\mathbb{0}$. These similarities with the other Cretan Hieroglyph inscriptions indicate a high probability that the reading direction suggested by Chapouthier [7] is correct.

The second row of Fig. 2 shows a transliteration of the Malia Altar Stone into a Cretan Hieroglyph script. The number below each Cretan Hieroglyph symbol is its numbering following Olivier et al. [14].

The third row of Fig. 2 shows a transliteration of the Malia Altar Stone into Anatolian Hieroglyph (or in parentheses Luwian) script. This transliteration as well as the number and syllabic value below each symbol follows the numbering by Woudhuizen [23].

The fourth and fifth rows of Fig. 2 show a transliteration of the Malia Altar Stone into the Carian alphabet [22] and the Old Hungarian alphabet [9, 10], respectively. For the Old Hungarian transliteration, the 
symbol $(1$ is a version of 1 from the Nagyszentmiklós gold treasure's cup number 23 , which is variously dated between the 8th and the 10th centuries (see [10], page 157). Similarly, $\boldsymbol{A}$ is a version of $\mathbb{\Lambda}$ from the Constantinople Old Hungarian inscription from 1515 (see [10], page 193).

Table 2 lists the sound values of the Cretan Hieroglyph symbols that are known from previous translations [18, 19]. There is generally a phonetic agreement among the Cretan Hieroglyph, the Carian and the Old Hungarian symbols with only a few exceptions. The exceptions appear in the underlined Carian sound values. We believe that the Carian letters $\varphi_{\text {and }}+$ originally had sound values closer to the corresponding Old Hungarian letters and their listed / $/ \mathrm{t} /$ and $/ \mathrm{x} /$ sound values are likely later developments under the influence of the Greek letters for theta $\theta$ and chi $\chi$.

The initial sounds of the Anatolian Hieroglyph syllabic values often differ from the rest of the sound values. Hence our translation is based on the Cretan Hieroglyph symbol and the Old Hungarian sound values because they seem to support each other and appear more reliable than either the Anatolian Hieroglyph or the Carian sound values.

Our translation is shown at the bottom of Fig. 2. The translation reads "Szem-jödnek hadd lá-m östenu," after filling in the missing vowels, the word beginning $/ \mathrm{h} /$ and the second /d/. Forrai [9] gives examples where word beginning $/ \mathrm{h} /$ and doubling of consonants are omitted. The translation means in English "For your eyes that you may see God."

The translation makes sense considering the possible use of the Malia Altar Stone. The cup-like cavity of the Malia Altar Stone was likely filled with some liquid that was sprinkled on the face and eyes of the people as part of some religious ceremony. The people attending the ceremony may have felt that their spiritual eyes were cleansed and afterwards could see God. The liquid could even have had hallucinogenic powers and may have been also drunk by the Minoan faithful.

In the first word of the translation, the root is the Proto-Ugric *szem (eye). It is followed by an agglutinative suffix, where $*$-jeid $>$-jöd denotes 'second person possessive case and plural number of objects' and -nek denotes the preposition 'for.' Hence szem-jödnek means 'for your eyes.'

The expression 'hadd lám' means 'let me see' or 'let you see.' The word 'hadd' contains a Proto-Uralic root with cognates Hungarian 'hagy' (to let) and Mansi 'kolj' (to let) with a second person imperative mood, meaning 'you let.' The word 'lám' derives from a ProtoUralic root from which the Proto-Hungarian 'lát' (to see) derives.

Finally, the word 'östenu' seems cognate with Hungarian 'isten' (god) and Hattian 'istanu' (sungod).

A possible variation of the above translation assumes that the last letter in the Old Hungarian transliteration is $Y_{\text {with a phonetic value } / t / \text {. In that case }}$ the last word would be isten-t. Since $-t$ is the Hungarian accusative suffix, the meaning of isten-t would be 'to see god-accusative-suffix.'

Table 2. Cretan Hieroglyph symbols and their IPA phonetic values.

\begin{tabular}{|c|c|c|c|c|c|}
\hline 001 से & $\mathrm{m}$ & 041 त्र & $\int$ & 081 数 & \\
\hline $002 \&$ & $\mathrm{~m}$ & 042 Ф & $\mathrm{s}$ & $082 \Leftrightarrow$ & \\
\hline 003 等 & $\mathrm{k}$ & 043 ๆึ & $\mathrm{s}$ & $083 \leftrightarrow$ & \\
\hline 004 \& & $\mathrm{a}$ & 044\{ & & 084 ฟ & \\
\hline 005 ي & f & 045 & & $085 A$ & \\
\hline 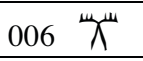 & & 046 Љ & $\mathrm{n}$ & $086 \pi$ & \\
\hline $007 \bigcup$ & $\mathrm{s}$ & $047 \bigcirc$ & $\mathrm{j}$ & $087 R$ & \\
\hline $008 \gamma^{\prime \prime \prime}$ & $\varepsilon$ & 048 中 & $\mathrm{i}$ & $088 \not$ & $\mathrm{p}$ \\
\hline 009 马 & $\varepsilon$ & $049 \propto$ & & $089 \not 2$ & $\mathrm{n}$ \\
\hline 010 P & 1 & $050 \uparrow$ & $* \mathrm{t}$ & $090 \times$ & \\
\hline $011 \circlearrowright$ & b & $051 \quad \Delta$ & $\mathrm{a}$ & $091 \mathrm{MM}$ & \\
\hline 012 & & 052 2\$ & 1 & 092 乌 & $\mathrm{n}$ \\
\hline $013 \circlearrowright$ & & $053 \curlyvee$ & é & $093 \bigwedge$ & $\mathrm{g}$ \\
\hline 014 & & $054 @$ & $\mathrm{v}$ & 094 A & 1 \\
\hline 015 زٔ & & 055 繁 & $\mathrm{g}$ & $095 \boldsymbol{\ell}$ & \\
\hline$0 1 6 \longdiv { . 5 }$ & & 056 吕 & $\varnothing$ & 096 p & \\
\hline $017 \lessdot$ & & $057 \quad \Psi^{4}$ & & $\underline{\text { Logogram }}$ & \\
\hline 018 غ્ & & $058 \mathbb{Q}$ & & 153 Ж & 1 \\
\hline $019 \forall$ & $\mathrm{h}$ & $059 \quad \Upsilon$ & & 154 M & 3 \\
\hline $020 \quad 55$ & $\mathrm{~m}$ & 060 & $\mathrm{p}$ & $156 \bar{\gamma}$ & \\
\hline 021 o & & $061<$ & $\mathrm{k}$ & 161 递 & \\
\hline 022 着 & & $062 \uparrow$ & d & $162 \mho$ & \\
\hline 023 (M) & 3 & 063 & d & $164 B_{x}$ & \\
\hline $024 Y^{X}$ & $\mathrm{r}$ & $064 \phi$ & & $166 \oiint$ & \\
\hline 025 米 & $\mathrm{n}$ & 065 ! & $\mathrm{s}$ & 168 造 & $\mathrm{n}$ \\
\hline 026 rex & & 066 & $\widehat{\mathrm{j} j}$ & $169 r$ & \\
\hline 027 抄 & $\mathrm{t}$ & 067 非 & nd & $170 \bigoplus$ & \\
\hline $028 \psi^{y}$ & $\mathrm{p}$ & 068 非 & $\mathrm{u}$ & $171 \quad \beta$ & \\
\hline 029 ي & $\mathrm{u}$ & 069 & $\widehat{c c ̧}$ & $172 \ominus$ & \\
\hline 030 䒺 & $\mathrm{Z}$ & 070 of & d & $173 \curvearrowright$ & \\
\hline $031 Y$ & 3 & 071 & & $179 f$ & \\
\hline 032 ק & $\mathrm{z}$ & $072 \triangle$ & $\mathrm{k}$ & $180 \ell$ & \\
\hline 033 公 & & $073 \bigcirc$ & & 304 & \\
\hline $034 \ll$ & $\mathrm{m}$ & $074 \odot$ & & $305 \quad$ & \\
\hline 035 口 & & $075 \odot$ & & $308 \quad \mathbf{L}$ & \\
\hline 036 | & & 076 & & $309 \quad \mathbf{Z}$ & \\
\hline 037 त्रि & $\mathrm{z}$ & 077 궁 & $\int$ & 11 & \\
\hline 038 四 & $\mathrm{n}$ & $078 \quad$ † & $\mathrm{k}$ & $10 \bullet$ & \\
\hline 039 . & & 079 仡 & & $100 \quad 0$ & \\
\hline 040 & $\mathrm{o}$ & $080 \quad 5$ & & 10000 & \\
\hline
\end{tabular}


The precise origin of the Hungarian $-t$ accusative suffix is unknown because it is not shared with Khanty and Mansi but still occurs in some of the earliest extant texts such as a funeral sermon from 1192 [2]. On the other hand, the $-t$ accusative suffix is not applied consistently in the early texts and is often omitted.

Either translation implies a belief in the spiritual power of liquids. That belief recalls Minoan and later Greek libation offerings and several ancient Near Eastern parallels [12]. Libations may have been intended to revivify the dead by some magic power of the offered liquid, which was often blood, wine, oil or milk.

\section{Conclusions and future work}

In this paper, we presented a translation of the Malia Altar Stone inscription. Our translation uses a synoptic transliteration into scripts whose phonetic values are at least partially known. After a synoptic transliteration, it is easier to guess the original phonetic values of the symbols in the unknown script. That is similar to how in bioinformatics, the multiple alignment of related genomes can be used to generate a hypothetical genomic sequence of the common ancestor of the aligned genomes $[20,21]$.

The present translation extended our previous translations of the Phaistos Disk [17] and some shorter Cretan Hieroglyph inscriptions [18]. Like our earlier Phaistos Disk translation, the present translation also yielded a religious text. It requires more study whether our synoptic transliteration method can be applied to other Minoan inscriptions in order to develop a translation.

\section{References}

1. W. Achterberg, J. Best, K. Enzler, L. Rietveld, and F. Woudhuizen, The Phaistos Disc: A Luwian Letter to Nestor, Publications of the Henri Frankfort Foundation 13 (Amsterdam, Dutch Archaeological and Historical Society, 2004)

2. L. Benkő, Az Árpád-kor magyar nyelvü szövegemlékei (Budapest, ELTE, Régi Magyar Irodalomtudományi Intézet 1980)

3. S. Boutsikos, Malia altar stone, Available at: http://the-phaistos-disk.webnode.com/malia-altarstone/, (2014), downloaded May 11, 2017.

4. G. Brandt et al., Science, 342, 6155, 257-261 (2013).

5. J. Campbell, Occidental Mythology: The Masks of God (Viking Penguin, New York 1962)

6. J. Chadwick, The Decipherment of Linear B, (Cambridge University Press, 1958)

7. F. Chapouthier, Inscription hiéroglyphique gravée sur un bloc de calcaire, Bulletin de Correspondance Hellénique 62, 104-109, (1938)

8. Y. Duhoux, American Journal of Archaeology, 104, 3, 597-600 (2000)
9. S. Forrai, The Old Hungarian Writing from Ancient Times to the Present, (in Hungarian), (Antológia Kiadó, Budapest, Hungary 1994)

10. G. Hosszú, Heritage of Scribes: The Relation of Rovas Scripts to Eurasian Writing Systems, (Rovas Foundation Hungary, Budapest, Hungary 2013)

11. P.C. Kanellakis, G.M. Kuper, P.Z. Revesz, J. of Comp. and Sys. Sciences, 51, 1, 26-52 (1995)

12. N. Marinatos, Minoan Kingship and the Solar Goddess: A Near Eastern Koine, (University of Illinois Press, 2010).

13. J.-P. Olivier, Cretan writing in the second millennium B.C., World Archaeology. 17, 3, 377389 (1986).

14. J.-P. Olivier, L. Godart and J.-C. Poursat, Corpus Hieroglyphicarum Inscriptionum Cretae Études Crétoises 31, (De Boccard, Paris 1996)

15. P.Z. Revesz, Introduction to Databases: From Biological to Spatio-Temporal, (Springer, New York, 2010)

16. P.Z. Revesz, Proc. 4th ACM Int. Conf. on Bioinfo. and Comp. Bio., 731-734, (ACM Press, New York, USA, 2013)

17. P.Z. Revesz, A computational translation of the Phaistos Disk, In: Mathematical Models and Computational Methods (joint proceedings of AMCSEMMMAS-EAS, Agios Nikolaos, Crete, Greece), Imre J. Rudas, editor, INASE Press, 53-57, (2015)

18. P.Z. Revesz, A computer-aided translation of the Phaistos Disk, Int. Journal of Computers, 10, 94-100, (2016)

19. P.Z. Revesz, A computer-aided translation of the Cretan Hieroglyph script, Int. Journal of Signal Processing, 1, 127-133 (2016)

20. P.Z. Revesz, Bioinformatics evolutionary tree algorithms reveal the history of the Cretan script family, Int. Journal of Applied Mathematics and Informatics, 10, 67-76, (2016)

21. M. Shortridge, T. Triplet, P.Z. Revesz, M. Griep, R. Powers, Comp. Bio. and Chem., 35, 1, 24-33, (2011)

22. Wikipedia, "Carian alphabets," downloaded April 5, 2017. https://en.wikipedia.org/wiki/Carian alphabets

23. F. Woudhuizen, The Earliest Cretan Scripts, (Innsbrucker Beiträge zur Kulturwissenschaft 2006)

24. J. G. Young, Minos 31-32 (1996-1997[1999]) 379400.

25. P. Yule, Early Cretan Seals: A Study of Chronology, Marburger Studien zur Vor und Frühgeschichte 4 (Mainz 1981)

26. G. Zaicz, chief editor, Etimológiai Szótár: Magyar Szavak és Toldalékok Eredete, (Etymological Dictionary: Origin of Hungarian Words and Affixes), (Tinta Könyvkiadó, 2006). 